\title{
EVALUATION OF PHYSICO-CHEMICAL PARAMETERS OF DIFFERENT SHODHIT GUGGUL
}

\author{
MAYUREE A. PATEL1, SANJEEV R. ACHARYA*2, CAROL P. MACWAN³, TEJAS B. PATEL ${ }^{4}$, B. N. SUHAGIA ${ }^{5}$
}

1Institute of Pharmacy, Nirma University, S. G. Highway, Ahmedabad 382481, Gujarat, India, ${ }^{2}$ S. S. R. College of Pharmacy, Sayli, Silvassa (Affiliated to Savitribai Phule Pune University), ${ }^{2}$ Former Department of Pharmacognosy, Institute of Pharmacy, Nirma University, S. G. Highway, Ahmedabad 382481, Gujarat, India, ${ }^{3}$ Department of Pharmacognosy, Faculty of Pharmacy, Dharmsinh Desai University, College Road, Nadiad 387001, Gujarat, India, 4 Department of Pharmaceutics, Faculty of Pharmacy, Dharmsinh Desai University, College Road, Nadiad 387001, Gujarat, India, ${ }^{5}$ Department of Pharmaceutical Chemistry, Faculty of Pharmacy, Dharmsinh Desai University, College Road, Nadiad 387001, Gujarat, India Email: sanjeevracharya@gmail.com

Received: 23 Mar 2017 Revised and Accepted: 22 Jul 2017

ABSTRACT

Objective: The present study was aimed to identify the physicochemical data of shodhit guggul. Guggul is a gum-resin exudate from the plant Commiphora weightii (Arn.) Bhandari, belonging to Burseraceae family. In Ayurveda, guggul is always purified. This purification is known as Shodhan. Shodhan is a process by which guggul is made non-toxic, effective, suitable and fit for therapeutic purposes.

Methods: The seven different shodhan dravya were used to prepare shodhit guggul. They were evaluated by performing physicochemical parameters including five different extractive value; total ash, acid insoluble, water soluble and sulphated ash value; $\mathrm{pH}$, and loss on drying.

Results: Analytical results of raw guggul showed total ash, acid insoluble ash, water soluble ash and sulphated ash value to $5.36 \pm 0.04 \%$, $0.96 \pm 0.03 \%, 4.51 \pm 0.03 \%$ and $8.40 \pm 0.04 \%$ respectively. These all values of each shodhit guggul were different. The extractive value of raw guggul was comparable with standard value while the extractive value of each shodhit guggul was totally different. The $\mathrm{pH}$ value of $1 \% \mathrm{w} / \mathrm{v}$ and $10 \% \mathrm{w} / \mathrm{v}$ aqueous solution of raw guggul was $6.44 \pm 0.18$ though $\mathrm{pH}$ of each shodhit guggul was changed. The loss on drying of raw guggul was found to be $1.88 \pm 0.02 \% \mathrm{w} / \mathrm{v}$, however, this value was different for each shodhit guggul.

Conclusion: The present study revealed that the different shodhan process with specific shodhan dravya affects the physicochemical parameters. The analysis and comparison of the data showed the difference in the properties of seven shodhit guggul with respect to raw Guggul.

Keywords: Commiphora weightii, Shodhana process, Shodhan dravya, Physicochemical Parameters

(C) 2017 The Authors. Published by Innovare Academic Sciences Pvt Ltd. This is an open access article under the CC BY license (http://creativecommons.org/licenses/by/4.0/) DOI: http://dx.doi.org/10.22159/ijpps.2017v9i9.18668

\section{INTRODUCTION}

The traditional system of medicine is known as Ayurveda. In Ayurveda, drugs are obtained from plants, animals, and mineral origin. These sources of drugs can be divided into poisonous and nonpoisonous class. The crude drugs obtained from these sources are generally possessed unwanted impurities and toxic substances, which can lead to harmful effect to human body [1]. Some medicinal plants are not safe to use as they can receive many toxic and harmful phytoconstituents in them. These phytoconstituents should be removed from the raw drugs. All these poisonous drugs should be purified and converted into suitable safe dosage forms for therapeutic use. Hence purification is an important step towards their safe, effective and suitable usage. Toxic plants need to be purified by various methods. In Ayurveda, this process is known as Shodhana $[2,3]$

Sometimes the toxic components present in the plants are responsible for the therapeutic efficacy too. The main object of purification is not related with the complete removal of that constituent, but to reduce the amount of toxic elements and increase the therapeutic activity of the component. Shodhana is considered as a combined process that serves both purposes $[4,5]$.

According to the Ayurvedic history, guggul is considered as a God gift. In fact, it is mentioned as early as from 3000 to 10,000 y ago in the vedas, the holy scriptures of India for treating human illnesses. According to vedas guggul is describing as "Agni Sthana" and used for dhupa [6]. Commiphora genus is the source of oleo-gum-resin. The name Commiphora originates from the Greek words kommi means 'gum' and phero means 'to bear'. The majority of the species yield a fragrant oleo-gum-resin following damage to the bark [7, 8]. The common name for Commiphora species is 'corkwood' means "softness of the wood" and 'kanniedood' means "cannot die", an indication of the sustainability of the plant. Guggul was used externally as well as internally during the period of Charaka and Sushruta. Vagbhata has described the use of guggul as a drug of choice for medoroga and Vatavikaras [9].

According to sanskrit, guggul means "That which protect against disease". This property of guggul is widely used in ayurvedic applications as it removes toxic substances which are accumulated as a result of slow digestion and metabolism [10]. Guggul is one of the "broad spectrum" health products with a wide range of benefits. Guggul is always purified prior to its medicinal use. Traditionally, guggul is used as a combination with several herbs to enhance its effects [11].

Guggul is exudate oleo gum resin obtained from the stem bark of Commiphora weightii belonging to Burseraceae family [12]. Guggul mainly cultivated in India. It cultivates in dry regions of Rajasthan, Gujarat, Maharashtra, Karnataka, Saurastra and Kutch [13-15]. As Guggul is an exudate, unorganized drug having external impurities in the form of dust, stone, debris, dry leaves and other foreign materials. After purification, the herb becomes safer and more effective for use. Purified guggul reduced toxicity. It may be taken for a long time without any side effect. Adverse effects are associated with raw gum guggul (unpurified guggul). The raw guggul may lead to a headache, diarrhoea, anorexia, abdominal pain, skin rashes, irregular menstruation, mild gastrointestinal discomfort and with very high doses, liver toxicity. As raw guggul cannot be used directly. Guggul formulations should be prepared with shuddh guggul (purified guggul). It was reported that gastric irritancy reduced with purified guggul. The pharmacological action is found to be increased after shodhan (purification) of guggul. As shodhan is an important procedure for Guggul [16]. Guggul shodhan is important for increase the activity and decreases some side effect. No any data are available for its physicochemical parameters for the evaluation of purified 
guggul. So present work was taken up in the view to completely standardize the purified guggul in accordance to parameters of World Health Organization (WHO) Guidelines.

\section{MATERIALS AND METHODS}

\section{Materials}

Guggul was procured from Lallubhai Vrajlal Gandhi, Ahmedabad (Official crude drug supplier), Gujarat. The raw materials for different shodhit dravya were collected from the J. S. Ayurvedic College, College Road, Nadiad.

\section{Preparation of shodhit dravya (liquid media) for purification of guggul}

Shodhit dravya is a liquid media in which raw guggul was purified. Different shodhit dravyas were prepared using different ayurvedic methods. Their different methods of preparations are described as given below.

\section{Cow urine}

Fresh cow urine was collected from disease free cow. Collected fresh cow urine was stored in a sterile container for further use. Urine was filtered for removal of impurities and it was immediately used as shodhit dravya.

\section{Cow milk}

Fresh cow milk was collected from disease free cow. Collected fresh cow milk was stored in a sterile container for further use. Milk was filtered for removal of impurities and it was immediately used as media.

\section{Triphla kwath (decoction)}

For prepration of triphala kwath the course powder of harade, bahera and amla were taken in equal quantity. The mixture of these powders was transferred to an extraction vessel. For the preparation of kwath 1 part of triphala powder was extracted by using 16 parts of water. The resultant mixture was allowed to stand for $12 \mathrm{hrs}$. The mixture was boiled till one fourth of its original volume. The mixture was cooled at room temperature and marc was allowed to settle down. The mixture was filtered. The filtrate was used as triphala kwath for shodhan process of guggul [17].

\section{Vasa swaras}

For the preparation of vasa swaras (fresh leafy juice), the fresh leaves of Adhatoda vasika were collected. The leaves were washed with water and crushed in the mixture to prepare a slurry. The slurry was filtered to remove impurities [17].

\section{Vasa kwath (decoction)}

For the preparation of vasa, kwath accurately weighed the coarse powder of leaves of Adhatoda vasica. This powder was transferred to an extraction vessel. For the preparation of kwath, 1 part of vasika powder was extracted using 16 parts of water. The resultant mixture was allowed to stand for $12 \mathrm{hrs}$. The mixture was boiled till one fourth of its original volume. The mixture was cooled at room temperature and marc was allowed to settle down. The mixture was filtered and used as vasa kwath for shodhan process of guggul [17].

\section{Nirgundi swaras with haridra churna}

Fresh leaves of Vitex negundo were collected. The leaves were washed with water and cut into small pieces. These small pieces were soaked in water for overnight. The slurry was prepared with the help of hand mixture. The small amount of haridra powder was added. The mixture was filtered. The filtrate was used as nirgundi swaras with haridra churna for shodhan process of guggul [17].

\section{Water}

Water was used as such for purification of raw guggul.

\section{Preparation of shodhit guggul}

For the preparation of shodhit guggul, approximate $100 \mathrm{~g}$ of raw guggul was taken. Firstly, any apparently looking extraneous matter like sand, stone, glass etc. were removed from raw guggul. Raw guggul was triturated using mortar pastel to make it small and uniform pieces. Subsequently, raw guggul was placed over a piece of cotton cloth which was later tied with thread to loosely wrap the guggul to form a potali like a pouch. The potali was supported by a stainless steel rod and hanged in to extraction vessel (dolayantra) containing different shodhan dravya. Ensuring that the potali was completely dipped into the extraction fluids, and then extraction vessel was heated up to boiling of shodhan dravya. The potali was taken out after 2-3 hrs. Of boiling. Guggul was solubilized in shodhan dravya after boiling. Then it was filtered and concentrated to get syrupy mass. Concentrated guggul was poured in shallow tray smeared with cow ghee and dried at $60^{\circ} \mathrm{C}$. The dried mass is known as shuddh guggul or purified guggul. According to this method, different shodhit guggul was prepared, 1. Gomutra shodhit guggul (GMSG), 2. Godugdha shodhit guggul (GDSG), 3. Triphala kwath shodhit guggul (TKSG), 4. Vasaka swaras shodhit guggul (VSSG), 5. Vasaka kwath shodhit guggul (VKSG), 6. Nirgundi shodhit guggul (NSG), 7. Water shodhit guggul (WSG) [18-21].

\section{Physicochemical characterization of shodhit guggul}

\section{Determination of total ash value}

About 2-3g of shodhit guggul was taken in accurately weighed (A) crucible. Crucible was kept in a muffle furnace at $510^{\circ} \mathrm{C}$ for $5-6 \mathrm{hrs}$. Until it free from carbon. After $24 \mathrm{~h}$. the crucible was taken out from the furnace and reweighed (B). If the material was not converted in ash, above procedure was repeated till an ash was obtained. Allowed the residue to cool in a suitable desiccator for 30 minutes, and then weighed without delay. The difference between (B) and (A) give the total ash value. The percentage of total ash was calculated in $\mathrm{mg}$ per gm of air-dried material [22-24].

\section{Determination of acid insoluble ash}

Total ash was treated with $25 \mathrm{ml}$ of $2 \mathrm{~N} \mathrm{HCl}$ solution in a beaker, covered with a watch-glass and boiled gently for 5 minutes. The watch-glass was rinsed with $5 \mathrm{ml}$ of hot water and this liquid added to the beaker. The solution was filtered with help of ash less filterpaper (whatmann 42) and washed with hot water until the filtrate became neutral. The insoluble matter was collected on a filter paper. That insoluble matter was transferred to the original crucible, ignited by gradually increasing the heat to $510^{\circ} \mathrm{C}$ for $5-6 \mathrm{hrs}$. in a muffle furnace to constant weight. After $24 \mathrm{hrs}$ it was opened and weighted (C). The residue was allowed to cool in a suitable desiccator for 30 minutes and then weighed without delay. The (B) - (C) indicate the acid insoluble ash. The percentage of acid-insoluble ash content was calculated as mg per gm of air-dried material [22-24].

\section{Determination of water soluble ash}

Total ash was treated with $25 \mathrm{ml}$ of distilled water, covered with a watch-glass and boiled gently for 5 minutes. The solution was filtered with help of ash less filter-paper (whatmann 42). The insoluble matter was collected on an ash less filter-paper (whatmann 42). The filter paper containing the insoluble matter was transferred to the original crucible and ignited by gradually increasing the heat to $510^{\circ} \mathrm{C}$ for $5-6 \mathrm{hrs}$. in a muffle furnace. After 24 $h$. it was opened and weighted (C). The residue was allowed to cool in a suitable desiccator for 30 minutes and then weighed without delay. The water insoluble ash was deducted from total ash to get water soluble ash. The percentage of water -soluble ash content was calculated as mg per gm of air-dried material [22-24].

\section{Determination of sulphated ash}

Total ash was treated with $25 \mathrm{ml}$ of $2 \mathrm{~N} \mathrm{H}_{2} \mathrm{SO}_{4}$ solution. It was heated gently until white fumes were no longer evolved and ignited at $510^{\circ} \mathrm{C} \pm 25^{\circ} \mathrm{C}$ until the residue was completely incinerated. Crucible was cooled by putting in a desiccator containing silica gel and weighed accurately. The procedure was repeated till the ash was prepared. The percentage of sulphated ash was calculated as mg per gm of air-dried materials [22-24].

\section{Determination of extractive value}

$5 \mathrm{~g}$ of shodhit guggul was taken in a stoppered conical flask and 100 $\mathrm{ml}$ of solvent was added. Shake the flask continuously for $6 \mathrm{~h}$. and keep a side for $18 \mathrm{~h}$. After $24 \mathrm{~h}$. filter the solution. From that $25 \mathrm{ml}$ of 
filtrate was taken in accurately weighed porcelain dish. The solvent was completely evaporated to dryness to obtained residue. The residues were accurately weighed and calculated \% yield with reference to the $5 \mathrm{gm}$ of the sample. Petroleum ether, chloroform, ethyl acetate, methanol and water were taken as solvents for the determination of extractive values [22-24].

\section{Determination of $\mathrm{pH}$ value}

Accurately weighed $1 \mathrm{~g}$ and $10 \mathrm{~g}$ of shodhit guggul were dissolved in $10 \mathrm{ml}$ and $100 \mathrm{ml}$ of distilled water respectively. When the sample was completely soluble, it was filtered. The $\mathrm{pH}$ of the filtrate was determined using $\mathrm{pH}$ meter [22-24].

\section{Determination of loss on drying}

$5 \mathrm{~g}$ of the sample was placed in accurately weighed porcelain dish to record its initial weight. The sample was heated in hot air oven at $105^{\circ} \mathrm{C}$ for a regular time interval of 5 min until constant weight was obtained [22-24].

\section{RESULTS}

Guggul is exudate materials obtained from the plant stem. Physiochemical parameters were estimated based on the methods recommended by World Health Organization (WHO).

\section{Ash values}

The results of ash value determination are given in table 1. Results indicated different ash values of raw guggul and shodhit guggul.

\section{Extractive values}

The results of extractive value determination are given in table 2 . Results indicated the different extractive value of raw guggul and shodhit guggul.

Table 1: Ash value determination

\begin{tabular}{|c|c|c|c|c|}
\hline Samples & $\begin{array}{l}\text { Total ash \%w/w } \\
\text { mean } \pm S^{*}\end{array}$ & $\begin{array}{l}\text { Acid insoluble ash } \% \mathrm{w} / \mathrm{w} \\
\text { mean } \pm \mathrm{SD}^{*}\end{array}$ & $\begin{array}{l}\text { Water soluble ash \%w/w } \\
\text { mean } \pm S D^{*}\end{array}$ & $\begin{array}{l}\text { Sulphated ash \%w/w } \\
\text { mean } \pm \text { SD* }\end{array}$ \\
\hline Raw Guggul & $5.36 \pm 0.04$ & $0.96 \pm 0.03$ & $4.51 \pm 0.03$ & $8.40 \pm 0.04$ \\
\hline GMSG & $8.67 \pm 0.08$ & $2.51 \pm 0.10$ & $6.11 \pm 0.11$ & $9.92 \pm 0.17$ \\
\hline GDSG & $6.82 \pm 0.1$ & $1.04 \pm 0.19$ & $2.79 \pm 0.24$ & $9.90 \pm 0.30$ \\
\hline TKSG & $6.84 \pm 0.1$ & $1.06 \pm 0.24$ & $2.94 \pm 0.29$ & $8.52 \pm 0.23$ \\
\hline WSG & $6.69 \pm 0.19$ & $1.01 \pm 0.33$ & $0.60 \pm 0.19$ & $9.10 \pm 0.19$ \\
\hline VSSG & $11.17 \pm 0.2$ & $1.26 \pm 0.23$ & $4.81 \pm 0.22$ & $15.01 \pm 0.11$ \\
\hline VKSG & $15.74 \pm 0.13$ & $1.96 \pm 0.33$ & $3.96 \pm 0.13$ & $19.33 \pm 0.20$ \\
\hline NSG & $11.89 \pm 0.7$ & $1.81 \pm 0.19$ & $9.71 \pm 0.25$ & $9.02 \pm 0.45$ \\
\hline
\end{tabular}

SD*=Standard deviation n=3, GMSG: Gomutra shodhit guggul; GDSG: Godugdha shodhit guggul; TKSG: Triphala kwath shodhit guggul; VSSG: Vasaka swaras shodhit guggul; VKSG: Vasaka kwath shodhit guggul; NSG: Nirgundi shodhit guggul; WSG: Water shodhit guggul.

Table 2: Extractive value determination

\begin{tabular}{|c|c|c|c|c|c|}
\hline Samples & $\begin{array}{l}\text { Petroleum ether \% } \\
\mathrm{w} / \mathrm{v} \text { mean } \pm S D^{*}\end{array}$ & $\begin{array}{l}\text { Chloroform } \\
\% w / v \text { mean } \pm S^{*}\end{array}$ & $\begin{array}{l}\text { Ethyl acetate } \\
\% w / v \text { mean } \pm S D^{*}\end{array}$ & $\begin{array}{l}\text { Methanol } \\
\% w / v \text { mean } \pm S D^{*}\end{array}$ & $\begin{array}{l}\text { Water \%w/v } \\
\text { mean } \pm S D^{*}\end{array}$ \\
\hline Raw Guggul & $10 \pm 0.05$ & $48 \pm 0.07$ & $18 \pm 0.03$ & $57.6 \pm 0.03$ & $60 \pm 0.04$ \\
\hline GMSG & $11.2 \pm 0.13$ & $26.4 \pm 0.11$ & $12.8 \pm 0.24$ & $44.8 \pm 0.21$ & $52.8 \pm 0.16$ \\
\hline GDSG & $24 \pm 0.10$ & $29.6 \pm 0.21$ & $24 \pm 0.15$ & $38.6 \pm 0.23$ & $43.2 \pm 0.26$ \\
\hline TKSG & $4 \pm 0.24$ & $5.6 \pm 0.12$ & $4 \pm 0.34$ & $52 \pm 0.15$ & $59.2 \pm 0.14$ \\
\hline WSG & $14.4 \pm 0.22$ & $40.8 \pm 0.25$ & $15.2 \pm 0.21$ & $45.6 \pm 0.11$ & $36.8 \pm 0.11$ \\
\hline VSSG & $8 \pm 0.17$ & $28.8 \pm 0.36$ & $9.6 \pm 0.22$ & $44 \pm 0.26$ & $45.6 \pm 0.11$ \\
\hline VKSG & $9.6 \pm 0.19$ & $25.6 \pm 0.28$ & $10.4 \pm 0.42$ & $41.6 \pm 0.14$ & $45.6 \pm 0.05$ \\
\hline NSG & $8 \pm 0.20$ & $28 \pm 0.26$ & $10.4 \pm 0.35$ & $36.8 \pm 0.28$ & $38.4 \pm 0.13$ \\
\hline
\end{tabular}

SD*=Standard deviation n=3, GMSG: Gomutra shodhit guggul; GDSG: Godugdha shodhit guggul; TKSG: Triphala kwath shodhit guggul; VSSG: Vasaka swaras shodhit guggul; VKSG: Vasaka kwath shodhit guggul; NSG: Nirgundi shodhit guggul; WSG: Water shodhit guggul.

\section{pH Value}

The results of $\mathrm{pH}$ value determination are given in table 3 .

\section{Loss on drying}

The results of loss on drying determination are given in table 4 .

Table 3: pH determination

\begin{tabular}{ll}
\hline Samples & Mean \pm SD* $^{*}$ \\
\hline Raw Guggul & $6.44 \pm 0.18$ \\
GMSG & $7.87 \pm 0.37$ \\
GDSG & $7.08 \pm 0.25$ \\
TKSG & $4.08 \pm 0.35$ \\
WSG & $6.58 \pm 0.12$ \\
VSSG & $7.29 \pm 0.26$ \\
VKSG & $7.81 \pm 0.60$ \\
NSG & $6.69 \pm 0.40$ \\
\hline
\end{tabular}

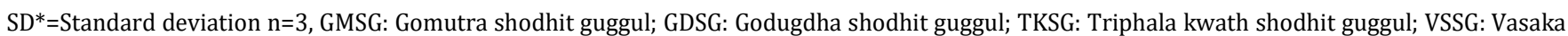
swaras shodhit guggul; VKSG: Vasaka kwath shodhit guggul; NSG: Nirgundi shodhit guggul; WSG: Water shodhit guggul. 
Table 4: Loss on drying determination

\begin{tabular}{ll}
\hline Samples & $\mathbf{0} \mathbf{w} / \mathbf{w}$ mean $\mathbf{\text { SD }}$ * \\
\hline Raw Guggul & $1.88 \pm 0.22$ \\
GMSG & $2.75 \pm 0.15$ \\
GDSG & $10.57 \pm 0.21$ \\
TKSG & $1.67 \pm 0.08$ \\
VSSG & $2.56 \pm 0.12$ \\
VKSG & $2.24 \pm 0.01$ \\
NSG & $8.24 \pm 0.12$ \\
WSG & $1.35 \pm 0.15$ \\
\hline
\end{tabular}

GMSG: Gomutra shodhit guggul; GDSG: Godugdha shodhit guggul; TKSG: Triphala kwath shodhit guggul; VSSG: Vasaka swaras shodhit guggul; VKSG: Vasaka kwath shodhit guggul; NSG: Nirgundi shodhit guggul; WSG: Water shodhit guggul.

\section{DISCUSSION}

Measurement of physicochemical parameters is a most important step for evaluation of the crude drugs [25]. The present study was carried out to identify these parameters for raw guggul and different shodhit guggul.

The residue remaining after incineration of plant material is known as ash value, which simply represents inorganic salts, naturally occurring in crude drug or adhering to it or intentionally added to it, as a form of adulteration. The ash value was determined by three different methods, which measured total ash, acid-insoluble ash, and water-soluble ash. The total ash method is employed to measure the total amount of material remaining after ignition. This includes both 'physiological ash' which is derived from the plant tissue itself, and 'non-physiological ash', which is the residue of the extraneous matter stick to the plant surface [26]. Additionally, the total ash of a crude drug also reflects the care taken in drug preservation, and the purity of crude and the prepared drug [27]. Ash values are important quantitative standards used to find out quality, identity and purity of crude drugs especially in the powder form [28-30].

Acid-insoluble ash is a part of total ash and measures the amount of silica present, especially as sand and siliceous earth. The value of total ash and acid insoluble ash indicates the difference between contaminating minerals and variations of the natural ash. Watersoluble ash is the water soluble portion of the total ash and sulphated ash value indicates the presence of non-volatilized residual substances [31].

As per WHO monograph, the standard value of total ash, acid insoluble ash and sulphated ash of raw guggul should not be more than $5 \%, 1 \%$ and $10 \%$ respectively [32]. Our results of raw guggul showed total ash value $5.36 \pm 0.04 \%$, acid insoluble ash $0.96 \pm 0.03 \%$, water soluble ash $8.51 \pm 0.03 \%$ and sulphated ash value $8.40 \pm 0.04 \%$. According to this data, the quality of raw guggul was upright.

The total ash value of each shodhit guggul showed the presence of inorganic impurities, minerals and earthy matter higher than the limit. The acid insoluble ash value of each shodhit guggul showed the presence of insoluble siliceous matter slightly higher than the limit. The water soluble ash value of each shodhit guggul was different. The sulphated ash value revealed the amount of non-volatilized residual substances within the limit except vasaka swaras shodhit guggul and vasaka kwath shodhit guggul.

The extractive values are valuable to estimate the chemical constituents present in the crude drug and furthermore assist in the evaluation of definite constituents soluble in a particular solvent. The water-soluble extractive value indicates the presence of polar substances like sugar, acids, gum and some inorganic compounds. The alcohol soluble extractive value indicates the presence of polar constituents like phenols, alkaloids, resinous materials, steroids, glycosides, flavonoids. The petroleum ether, chloroform and ethyl acetate soluble extractive value indicate the presence of some nonpolar compound like terpenoids, sterols, lipid, fats, and other impurities [31,33].

As per WHO monograph, the standard extractive value of alcoholic, water, and ethyl acetate for raw guggul should not be less than $35 \%$, $53 \%$, and $25 \%$ respectively [32]. There is no standard extractive value available for petroleum ether and chloroform. The each extractive value of raw guggul was correlated with standard value.

The water extractive value of each shodhit guggul was not correlated with the standard value except triphala shodhit guggul. This suggests that the shodhit dravya may affect the extractive value of the raw guggul. Similarly, our results revealed that the methanolic extractive value of each shodhit guggul was greater than the limit but it was not higher than the raw guggul value. This indicates that shodhan dravya may not decrease the methanolic extractive value of shodhit guggul. The ethyl acetate extractive values of each shodhit guggul were not correlated with the standard value. The petroleum ether extractive value of raw guggul was $10 \pm 0.05 \%$. This value of Godugdha shodhit guggul was higher than the raw guggul. It indicates that the higher value may be due to the cow milk content (content of shodhit dravya). The extractive value of Gomutra shodhit and water shodhit were slightly higher than the raw guggul. It suggests that shodhit dravya viz. gomutra and water does not affect the solubility of raw guggul. Petroleum ether extractive values of remaining shodhit guggul were less than the raw guggul. From that the value of triphala kwath was very less. Chloroform extractive value of raw guggul was $48 \pm 0.07 \%$. Chloroform extractive value of water shodhit guggul was very similar to raw guggul. While the value of triphala kwath shodhit guggul was very less than the raw guggul. The chloroform extractive value of remaining shodhit guggul was $50 \%$ decreases the value than the raw guggul. The whole data revealed that the water is a choice of shodhan dravya to obtain optimum chloroform extractive value while triphala kwath completely decreases the solubility of raw guggul. The other shodhit dravya efficiently affect the solubility of raw guggul.

The $\mathrm{pH}$ value of $1 \% \mathrm{w} / \mathrm{v}$ aqueous solution and $10 \% \mathrm{w} / \mathrm{v}$ aqueous solution of raw guggul was $6.44 \pm 0.18$. According to $\mathrm{pH}$ data it was indicated the acidic nature of guggul. The $\mathrm{pH}$ value of $1 \% \mathrm{w} / \mathrm{v}$ and $10 \% \mathrm{w} / \mathrm{v}$ water shodhit guggul was similar to raw guggul. The $\mathrm{pH}$ value of $1 \% \mathrm{w} / \mathrm{v}$ and $10 \% \mathrm{w} / \mathrm{v}$ triphala shodhit guggul and nirgundi shodhit guggul were indicated the acidic nature of that shodhit guggul. While the $\mathrm{pH}$ values of other shodhit guggul were nearer to alkaline.

The loss on drying is the loss of weight in percentage $\mathrm{w} / \mathrm{w}$ resulting from water and volatile matter of any kind that can be driven of under specified conditions. Deterioration of the plant material depends upon the amount of water or moisture present in plant material. If the water content is high, the plant can be easily deteriorated due to fungus and bacterial growth [34]. The less value of moisture content of drugs could prevent content bacterial, fungal or yeast growth through storage[35]. Deterioration time of the plant material depends upon the amount of water present in plant material. If the water content is high, the plant can be easily deteriorated due to fungus. The loss on drying of raw guggul at 105 ${ }^{\circ} \mathrm{C}$ was found to be $1.88 \pm 0.02 \% \mathrm{w} / \mathrm{w}$. The loss on drying value of each shodhit guggul was similar that of raw guggul except godugdha and nirgundi shodhit guggul. The value of godugdha may be due to the fats present in godugdha and for nirgundi may be due to volatile oil content.

\section{CONCLUSION}

The physicochemical parameter of raw guggul was available but there was not enough evidence for detailed physicochemical 
evaluation on seven shodhit guggul. Therefore present work was taken up in the view to completely standardize the purified guggul in accordance to parameters of World Health Organization (WHO) Guidelines and standard laboratory procedures. In present study was an investigated physicochemical character of different shodhit guggul to analyze their quality, safety and standardization for their safe use. The information of the present study will provide data which is helpful in the correct identification of purified guggul. This study suggested that shodhan process or shodhit dravya may affect the physicochemical parameters of the raw guggul.

\section{ACKNOWLEDGMENT}

The authors would like to express their thanks and gratitude to Dr. Pradip Vaishnav, the Principal of J. S. Ayurvedic College, Nadiad for providing support to conduct the research. Also thanks to Dr. Dharmendra Jani, Department of Dravyaguna, and Dr. Bharat Kansariya, Department of Rasashashtra, J. S. Ayurvedic College for providing the best research facilities and knowledge about the Ayurvedic method of preparation related to this work.

\section{AUTHORS CONTRIBUTION}

Mayuree Patel involved throughout the research work in the laboratory. Sanjeev Acharya provided knowledge about shodhan process of guggul. Carol Macwan and Tejas Patel contributed to evaluate physicochemical parameters. B. N. Suhagia provided support to conduct research work.

\section{CONFLICT OF INTERESTS}

No conflict of interest

\section{REFERENCES}

1. Maurya S, Seth A, Laloo D, Singh N, Gautam D Si, Singh A. Sodhana: an ayurvedic process for detoxification and modification of therapeutic activities of poisonous medicinal plants. Asian Sci Life 2015;34:188-97.

2. Dikshit M. Poisonous plants as medicine after shodhana a review. Unique J Ayur Herbal Med 2016;4:1-4.

3. Chaube A, Prajapati PK, Dixit SK. On the technique of sodhana. Ancient Sci Life 1996;16:67-73.

4. Morbale MS, Herwade AS. Concept of shodhan [Purification Method]. Int Ayur Med J 2015;3:2725-8.

5. Murulihar N, Mohan Kumar BN. A unique process: concept of shodhana. World J Pharm Pharm Sci 2016;5:657-63.

6. Rout OP, Acharya, Mishra S. Oleo gum resin guggul: a review of the medicinal evidence for its therapeutic properties. Int J Res Ayur Pharm 2012;3:15-21.

7. Poonia Priyanka, Mittal Sanjeev K. Review article gum guggul: an ayurvedic boom. Int J Pharmacogn Phytochem Res 2014;6:347-54.

8. Kokate CK, Purohit AP, Gokhale SB. Pharmacognosy. Edn. 46, Nirali Prakashan, Pune; 2008. p. 136-7.

9. Paraskeva MP. A phytochemical and pharmacological study of ten Commiphora species indigenous to South Africa, Thesis submitted to University of the Wiwatersrand, Johannesburg; 2007. p. 35-6.

10. Paranjpe P. Indian medicinal plants forgotten halers. The Chaukhamba Ayurvijnana studies 25, chaukhambha sanskrit pratishthan, Delhi; 2013. p. 91-3.

11. Taru P, Mukta A, Undale V, Bhosale A. Acute and subacute toxicity studies on shodhana processed guggul. Int J Pharm Sci Res 2013;4:796-9.

12. Pendyala V, Janga R, Suryadevara V. Phytochemical and pharmacological evaluation of Commiphora mukul for antidepressant activity in albino mice. Asia J Pharm Clin Res 2017;10:360-3.

13. Nadkarni KM. Indian material Medica with Ayurvedic, Unani, Tibbi, Siddha, Allopathic, Homeopathic, Naturopathic and Home remedies Appendices and Index, Bombay popular Prakashan; 1982. p. 167-70.
14. Kirtikar KR, Basu BD. Indian Medicinal Plants. Edn. 2. Vol. I. Bishen Singh Mahendra Pal Singh, Dehradun, India; 2004. p. 525-9.

15. Anonymous, The wealth of India, A Dictionary of Raw Materials and Industrial Product, Raw Materials, CSIR, India; 2012. p. 313-4.

16. Kamble R, Sathaye S, Shah DP. Evaluation of the antispasmodic activity of different shodhit guggul using different shodhan process. Indian J Pharm Sci 2008;70:368-72.

17. Shashtri K. Rasatarangini published by Motilal banarasi das;1903. p. 754-8.

18. Anonymous. The Ayurvedic Formulary of India, I (B); 1978. p. 41-2.

19. Anonymous. The Ayurvedic Pharmacopoeia of India. Government of India Ministry of Health and Family Welfare Department of AYUSH Part-I; 2008. p. 56-7.

20. Anonymous. The Ayurvedic Pharmacopoeia of India. Government of India Ministry of Health and Family Welfare Department of AYUSH Part-I, Second Edition; 2016. p. 203-24.

21. Anonymous. The Ayurvedic Pharmacopoeia of India Government of India Ministry of Health and Family Welfare Department of AYUSH; 2007. p. 168-73.

22. Anonymous. Quality control methods for medicinal plant materials, World health Organization, Geneve, A. I. T. B. S. Publishers and Distributors, New Delhi; 2002. p. 28-33.

23. World Health Organization, (WHO), Final text for revision of the international pharmacopoeia; 2012. p. 1-2.

24. Mukherjee PK. Quality control of herbal drugs. Horizons pharmaceutical publishers; 2012. p. 186-93.

25. Regupathi T, Chitra K. Physicochemical analysis of medicinal herbs, Eclipta alba (L.) Hass and Lippia nodiflora (Linn.). Int J Pharm Phytopharm Res 2015;4:249-51.

26. Purohit AP, Kokate CK, Gokhale SB. Pharmacognosy $13^{\text {th }}$ Edition. Nirali Prakashan India; 2005. p. 256-9.

27. Rajesh P, Latha S. "Capparis sepiaria Linn.-pharmacognostical standardization and toxicity profile with chemical compounds identification (GC-MS)". Int J Phytomed 2010;2:71-9.

28. Swamy P, Mulla SK. Preliminary pharmacognostical and phytochemical evaluation of Portulaca quadrifida Linn". Int J Pharm Tech Res 2010;2:699-702.

29. Patnia S, Saha AN. Physicochemical, phytochemical and elemental analysis of stem bark and roots of Berberis asiatica. Adv Appl Sci Res 2012;3:3624-8.

30. Mritunjay Kumar, Mondal P, Borah S, Mahato K. Physicochemical evaluation, preliminary phytochemical investigation, fluorescence and TLC analysis of leaves of the plant Lasia spinose (Lour) thwaites. Int J Pharm Pharm Sci 2013;5:306-10.

31. Shwetajain, Sharma C, Khatri P, Jain A, Vaidya A. Pharmacognostic and phyto chemical investigations of the leaves of Zizyphus xylopyrus (Retz) willd. Int J Pharm Pharm Sci 2011;3:122-5.

32. Anonymous. WHO Monograph on selected medicinal plants. Vol. 3; 2009. p. 177-89.

33. Kripa KG, Sangeetha R, Chamundeeswari D. Pharmacognostical and physicochemical evaluation of the plant Leucas aspera. Asian J Pharm Clin Res 2016;9:263-8.

34. Pandey MK, Singh GN, Sharma Rajeev $\mathrm{Kr}$, Lata Sneh. Standardization of yakritplihantak churna. An ayurvedic poly herbal formulation. Int J Pharm Sci Res 2012;3:171-6.

35. Purwantiningsih, Purwantin I, Djoko S. Identification of standard parameters of kepel leaves [Stelechocarpus Burahol (BI.) Hook. F. and Th.] and the extract as raw material for antihyperuricemic medicaments. Asian J Pharm Clin Res 2011;4:149-53.

\section{How to cite this article}

- $\quad$ Mayuree A Patel, Sanjeev R Acharya, Carol P Macwan, Tejas B Patel, B N Suhagia. Evaluation of physicochemical parameters of different shodhit guggul. Int J Pharm Pharm Sci 2017;9(9):247-251. 